Correspondence

Kris A. Willems

kwi@scientiaterrae.org

Received 6 March 2008

Revised 23 May 2008

Accepted 29 May 2008

\title{
Genetic and physiological diversity of Tetragenococcus halophilus strains isolated from sugar- and salt-rich environments
}

\begin{abstract}
Annelies Justé, ${ }^{1,2,3}$ Bart Lievens, ${ }^{2,3}$ Ingeborg Frans, ${ }^{2,3}$ Terence L. Marsh, Michael Klingeberg, ${ }^{5}$ Chris W. Michiels ${ }^{1}$ and Kris A. Willems ${ }^{2,3}$

${ }^{1}$ Laboratory of Food Microbiology and Leuven Food Science and Nutrition Research Centre (LFoRCe), Department Microbial and Molecular Systems, Katholieke Universiteit Leuven, B-3001 Leuven, Belgium

${ }^{2}$ Research Group Microbial Ecology and Biorational Control, Scientia Terrae Research Institute, B-2860 Sint-Katelijne-Waver, Belgium

${ }^{3}$ Research Group Process Microbial Ecology and Management and Leuven Food Science and Nutrition Research Centre (LFoRCe), Department Microbial and Molecular Systems, Katholieke Universiteit Leuven Association, De Nayer Institute, B-2860 Sint-Katelijne-Waver, Belgium

${ }^{4}$ Center for Microbial Ecology, Michigan State University, East Lansing, Michigan 48824, USA

${ }^{5}$ Department of Biotechnology, Südzucker AG, Mannheim/Ochsenfurt, ZAFES, Obrigheim/Pfalz, Germany
\end{abstract}

\begin{abstract}
Tetragenococcus halophilus is known to flourish in extreme salt environments. Recently, this halophilic bacterium also appeared as the dominant microflora during storage of sugar thick juice, an intermediate product of beet sugar production. Although T. halophilus can cause degradation of thick juice, dominance of this bacterium does not always result in degradation. In this study T. halophilus strains from high-salt and high-sugar environments, and in particular from degraded and non-degraded thick juice, were compared in detail. Both physiological and genetic characterization using Biolog, repetitive PCR fingerprinting (rep-PCR) and random amplified polymorphic DNA (RAPD) technology, revealed clear differences between T. halophilus strains isolated from salt- and sugar-rich environments. However, no strain pattern could be specifically and systematically associated with degraded or non-degraded thick juice. Remarkably, halophilic T. halophilus strains were not able to grow in sugar thick juice. Irrespective of the differences between the strains from high-salt or high-sugar environments, DNA-DNA hybridization grouped all strains within the species $T$. halophilus, except one isolate from sugar thick juice that showed different physiological and genetic characteristics, and that may represent a new species of Tetragenococcus.
\end{abstract}

\section{INTRODUCTION}

At present, the genus Tetragenococcus comprises four species: T. halophilus (Collins et al., 1990), T. muriaticus (Satomi et al., 1997), T. solitarius (Ennahar \& Cai, 2005) and T. koreensis (Lee et al., 2005). The species T. halophilus and T. muriaticus, both homofermentative lactic acid bacteria, play an important role in halophilic fermentation processes such as the production of soy sauce, soy paste, brined anchovies, fish sauce, Japanese fermented puffer fish

Abbreviations: RAPD, random amplified polymorphic DNA; rep-PCR, repetitive PCR fingerprinting.

The GenBank/EMBL/DDBJ accession numbers for the sequences determined in this work are given in Fig. 2. ovaries, Indonesian 'terasi' shrimp paste and fermented mustard (Ito et al., 1985; Villar et al., 1985; Röling et al., 1994; Röling \& van Verseveld, 1996; Kobayashi et al., 2000, 2003; Thongsant et al., 2002; Chen et al., 2006). However, recently, Willems et al. (2003) detected T. halophilus in concentrated sugar thick juice, an intermediate in the production of beet sugar. Subsequently, T. halophilus was reported as the dominant microflora in this sugar-rich environment and as a probable cause of thick juice degradation, which is characterized by a reduction in $\mathrm{pH}$ from $\mathrm{pH} 9$ to 5-6 and, typically, an increase in reducing sugar content resulting in economic losses (Sargent et al., 1997; Willems et al., 2003; Justé et al., 2008b). Nevertheless, the dominance of this bacterium in equally conditioned tanks of thick juice does not always result in degradation, 
suggesting that different strains of T. halophilus might be responsible for the different effects during storage (Justé et al., 2008b). Consequently, a more detailed characterization, based on the genetic and physiological diversity of the T. halophilus strains isolated from degraded and nondegraded thick juice, was undertaken to elucidate this controversy and provide options for effective control of thick juice degradation.

In this study, we characterized 25 isolates of Tetragenococcus obtained from thick juice using random amplified polymorphic DNA (RAPD) fingerprinting. Based on these results, an extensive genetic and physiological characterization of nine Tetragenococcus strains isolated from both degraded and non-degraded thick juice (further referred to as 'osmophilic tetragenococci') was performed, in comparison with seven strains isolated from a high-salt environment (further referred to as 'halophilic tetragenococci'). At the genetic level, strains were further compared by $16 \mathrm{~S}$ rRNA gene sequencing, repetitive PCR fingerprinting (rep-PCR), and DNA-DNA hybridization. The physiological characterization included substrate utilization patterns and growth in salt-rich and sugar-rich media.

\section{METHODS}

Bacterial strains. Twenty-five representative strains (Table 1) were selected from a large collection of thick juice tetragenococci (Justé et al., 2008a, b) for use in this study. In order to ensure a wide diversity, the strains were isolated from different geographical origins, and from degraded and non-degraded thick juice samples to which hop acids had been added or not. One strain was identified as $T$. muriaticus, the others as T. halophilus based on a species-specific PCR (Justé et al., 2008a). T. halophilus strains from salt-rich environments were purchased from the BCCM/LMG Bacteria Collection (Ghent, Belgium), the Japanese Collection of Micro-organisms (JCM; Hirosawa, Japan) or the Institute of Applied Microbiology (IAM; University of Tokyo, Japan) (Table 1). Strains were cultured on Tryptone Soy Agar (TSA) at $30{ }^{\circ} \mathrm{C}$. Stock cultures were maintained in $15 \%(\mathrm{v} / \mathrm{v})$ glycerol at $-80{ }^{\circ} \mathrm{C}$.

DNA extraction. Genomic DNA was extracted using the phenol/ chloroform extraction method as described before (Lievens et al., 2003). For DNA-DNA hybridization, DNA extractions were performed by the method of Wilson (1987) with minor modifications (Cleenwerck et al., 2002).

RAPD fingerprinting. To select discriminative RAPD primers to type Tetragenococcus strains, initially 10 decamer oligonucleotides, randomly selected from the Operon primer kits (Operon Technologies), were screened on a subset of the strains listed in Table 1. The best three primers that led to the production of clear, distinct, reproducible and polymorphic bands were selected for further analysis. These were RAP1 (CAGCACTGAC), RAP3 (AGGGTCGTTC) and RAP6 (GGGCCGTCT). Amplification was performed in a total volume of $20 \mu \mathrm{l}$ containing $0.5 \mu \mathrm{M}$ of the single random primer, $0.15 \mathrm{mM}$ of each deoxynucleoside triphosphate, 1.0 U Titanium Taq DNA polymerase (Clontech Laboratories) and $1 \mathrm{ng}$ genomic DNA. Before amplification, DNA samples were denatured at $94{ }^{\circ} \mathrm{C}$ for $2 \mathrm{~min}$. Subsequently, 35 cycles were run of $1 \mathrm{~min}$ at $94{ }^{\circ} \mathrm{C}, 1 \mathrm{~min}$ at $35^{\circ} \mathrm{C}$, and 2 min at $72{ }^{\circ} \mathrm{C}$, with a final extension step at $72{ }^{\circ} \mathrm{C}$ for $10 \mathrm{~min}$. RAPD-PCR products were separated by loading $10 \mu \mathrm{l}$ of the reaction volume on $1.5 \%$ agarose gels followed by $120 \mathrm{~min}$ electrophoresis at $4 \mathrm{~V} \mathrm{~cm}^{-1}$ in $1 \times$ Tris/ acetate-EDTA (TAE) buffer, stained with ethidium bromide, and visualized with UV light. A $1 \mathrm{~kb}$ DNA ladder (Smartladder; Eurogentec) was used as size marker. Gel images were acquired with the BioChemi System (UVP, Upland, CA, USA). Image data were processed by using GelCompar software, version 4.6.1 (Applied Maths). After normalization and background subtraction, the levels of similarity between RAPD-PCR fingerprints were calculated by using the Pearson correlation coefficient. Cluster analysis was performed on three gels, optioned with three different RAPD primers. and was performed by the unweighted pair group method (UPGMA). The different RAPD primers resulted in similar clustering (data not shown). All RAPD reactions were performed in triplicate to check reproducibility.

$16 S$ rRNA gene sequence analysis. The nearly complete $16 \mathrm{~S}$ rRNA gene was amplified by PCR with the universal bacterial primers $27 \mathrm{~F}$ and 1492R (Lane, 1991). The target DNA (1 ng) was amplified in a total volume of $20 \mu \mathrm{l}$ containing $0.3 \mu \mathrm{M}$ of each primer, $0.3 \mathrm{mM}$ of each deoxynucleoside triphosphate, $1 \mathrm{mM} \mathrm{MgSO}_{4}, 2 \times P f x$ amplification buffer, $2 \times$ PCR Enhancer and 1.0 U Platinum $P f x$ DNA polymerase (Invitrogen). Before amplification, DNA samples were denatured at $94{ }^{\circ} \mathrm{C}$ for $2 \mathrm{~min}$. Subsequently, 30 cycles were run of $15 \mathrm{~s}$ at $94{ }^{\circ} \mathrm{C}, 30 \mathrm{~s}$ at $59{ }^{\circ} \mathrm{C}$, and $90 \mathrm{~s}$ at $72{ }^{\circ} \mathrm{C}$, with a final extension step at $72{ }^{\circ} \mathrm{C}$ for $10 \mathrm{~min}$.

Sequencing was performed on purified PCR products with the same primers 27F and 1492R. Samples were analysed on an Applied Biosystems 373A Automated Sequencer. A search for sequence similarities was performed using the BLAST (Altschul et al., 1997) algorithm to screen GenBank (Benson et al., 2004). All sequences were deposited in GenBank under the accession numbers shown in Fig. 2. Multiple sequence alignment was performed using CLUSTAL_X. Phylogenetic analyses were performed using the neighbour-joining algorithm of the CLUSTAL_X software package. Phylogenetic trees were constructed using CLUSTAL_X and visualized using TreeView.

rep-PCR fingerprinting. To select a good rep-PCR primer (pair) to characterize Tetragenococcus species, two single oligonucleotides, BOXA1R (CTACGGCAAGGCGACGCTGACG) and (GTG) $)_{5}$, and one primer pair, REP1R-I (IIIICGICGICGICATCIGGC) and REP2-I (ICGICTTATCIGGCCTAC), were initially tested on a subset of five Tetragenococcus strains. PCR conditions were as described by Versalovic et al. (1994). In contrast to primer BOXA1R, which generated only $1-3$ bands, the (GTG) $)_{5}$ primer and the REP1R-I and REP2-I primer set had good discriminative abilities, yielding 2-13 bands for each isolate. Nevertheless, since some products generated with primer $(\mathrm{GTG})_{5}$ did not migrate from the slots during gel electrophoresis, the REP1R-I and REP2-I primer set was chosen for further analyses.

REP-PCR analysis was performed in a total volume of $20 \mu \mathrm{l}$ containing $0.5 \mu \mathrm{M}$ of each primer, $0.15 \mathrm{mM}$ of each deoxynucleoside triphosphate, 1.0 U Titanium Taq DNA polymerase, and $1 \mathrm{ng}$ genomic DNA. Before amplification, DNA samples were denatured at $94{ }^{\circ} \mathrm{C}$ for $2 \mathrm{~min}$. Subsequently, 35 cycles were run of $1 \mathrm{~min}$ at $94{ }^{\circ} \mathrm{C}, 1 \mathrm{~min}$ at $40{ }^{\circ} \mathrm{C}$, and $4 \mathrm{~min}$ at $72{ }^{\circ} \mathrm{C}$, with a final extension step at $72{ }^{\circ} \mathrm{C}$ for $10 \mathrm{~min}$. REP-PCR products were separated and visualized as described above, and image data were processed as for the RAPD analyses. All REP-PCR reactions were performed in duplicate to check reproducibility.

DNA-DNA hybridization. DNA-DNA hybridizations were performed according to a modification (Goris et al., 1998; Cleenwerck et al., 2002) of the microplate method described by Ezaki et al. (1989). The hybridization temperature was $35^{\circ} \mathrm{C}$ and reciprocal reactions (e.g. $\mathrm{A} \times \mathrm{B}$ and $\mathrm{B} \times \mathrm{A}$ ) were performed. DNA-binding values reported 
Table 1. Tetragenococcus strains used in this study, isolated from both thick juice (osmophilic strains) and salt-rich environments (halophilic strains)

\begin{tabular}{|c|c|c|c|c|c|c|}
\hline \multirow[t]{2}{*}{ Geographical origin } & \multirow[t]{2}{*}{ Isolate } & \multirow[t]{2}{*}{ Source } & \multirow{2}{*}{$\begin{array}{l}\text { Isolation date or culture } \\
\text { collection number }\end{array}$} & \multirow[t]{2}{*}{ RAPD group $\dagger$} & \multicolumn{2}{|c|}{ Nearest match using BLAST analysis } \\
\hline & & & & & Organism & Similarity (\%) \\
\hline \multicolumn{7}{|c|}{ Osmophilic strains } \\
\hline \multicolumn{7}{|l|}{ Belgium } \\
\hline Tienen & T1‡ & Degraded thick juice & 2006 & I & T. muriaticus & 98 \\
\hline Tienen & T3‡ & Non-degraded thick juice & 2005 & II & T. halophilus & 99 \\
\hline Tienen & T4 & Non-degraded thick juice & 2006 & II & T halophilus & 99 \\
\hline Tienen & T5 & Degraded thick juice & 2005 & II & T. halophilus & 99 \\
\hline Tienen & T7 & Non-degraded thick juice & 2006 & II & T. halophilus & 99 \\
\hline Tienen & T9‡ & Non-degraded, hop-treated thick juice & 2004 & II & T. halophilus & 99 \\
\hline Tienen & T10 & Degraded thick juice & 2007 & II & T. halophilus & 99 \\
\hline Genappe & T52 (ID4406) & Degraded thick juice & 1997 & II & T. halophilus & 99 \\
\hline Genappe & T53 (ID4407) & Degraded thick juice & 1997 & II & T. halophilus & 99 \\
\hline \multicolumn{7}{|l|}{ Germany } \\
\hline Zeitz & T6‡ & Degraded thick juice & 2000 & III & T. halophilus & 99 \\
\hline Zeitz & T20 & Non-degraded thick juice & 2007 & III & $\mathrm{ND}$ & \\
\hline Zeitz & T25 & Non-degraded thick juice & 2007 & III & ND & \\
\hline Zeitz & T26 & Non-degraded thick juice & 2007 & III & ND & \\
\hline Zeitz & T27 & Non-degraded thick juice & 2007 & III & ND & \\
\hline Zeitz & T47 & Degraded thick juice & 2007 & III & ND & \\
\hline Zeitz & T49 & Degraded thick juice & 2007 & III & $\mathrm{ND}$ & \\
\hline \multicolumn{7}{|l|}{ France } \\
\hline Guignicourt & $\mathrm{T} 2 \ddagger$ & Non-degraded thick juice & 2006 & IV & T. halophilus & 99 \\
\hline Roye & T29 & Degraded thick juice & 2007 & IV & $\mathrm{ND}$ & \\
\hline Roye & T30 & Degraded thick juice & 2007 & IV & $\mathrm{ND}$ & \\
\hline Guignicourt & T31 & Non-degraded thick juice & 2007 & IV & ND & \\
\hline Guignicourt & T32 & Non-degraded thick juice & 2007 & IV & ND & \\
\hline Roye & T33 & Non-degraded thick juice & 2006 & IV & $\mathrm{ND}$ & \\
\hline Roye & T34 & Non-degraded thick juice & 2006 & IV & $\mathrm{ND}$ & \\
\hline Eppeville & T35 & Non-degraded thick juice & 2006 & IV & ND & \\
\hline Eppeville & T36 & Non-degraded thick juice & 2006 & IV & $\mathrm{ND}$ & \\
\hline \multicolumn{7}{|c|}{ Halophilic strains } \\
\hline Belgium & $\mathrm{T} 11^{\mathrm{T}} \ddagger$ & Anchovy pickles & LMG $11490^{\mathrm{T}}$ (ATTC 33315) & $\mathrm{V}$ & T. halophilus & 99 \\
\hline Belgium & $\mathrm{T} 12^{\mathrm{T}} \ddagger$ & Squid liver sauce & LMG $18498^{\mathrm{T}}$ & VI & T. muriaticus & 99 \\
\hline Japan & T13 $\ddagger$ & Fermented soybean mash & IAM 1673 (ATTC 13621) & $\mathrm{V}$ & T. halophilus & 99 \\
\hline Japan & T14 & Soy sauce brewing mashes & IAM 1674 (NISL 7118) & $\mathrm{V}$ & T. halophilus & 99 \\
\hline Japan & T15 & Soy sauce brewing mashes & IAM 1675 (NISL 7126) & $\mathrm{V}$ & T. halophilus & 99 \\
\hline Japan & T18 & Fermented shrimps & JCM 2014 & VII & Pediococcus sp. & 100 \\
\hline Japan & T19 & Fermented small fish & JCM 2015 & $\mathrm{~V}$ & T. halophilus & 99 \\
\hline
\end{tabular}

ND, Not determined.

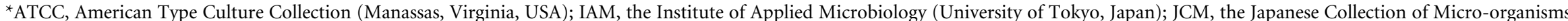
(Hirosawa, Japan); LMG, BCCM/LMG Bacteria Collection (Ghent, Belgium).

$\overrightarrow{\mathrm{o}} \quad \dagger \mathrm{RAPD}$ grouping was based on a RAPD analysis using primer RAP3 (Fig. 1).

$\ddagger$ Strains selected for further characterization. 
are mean values of at least four hybridization experiments, including the reciprocal reactions.

Carbon source metabolic fingerprint. Utilization of 95 different carbon sources was tested in the Biolog MicroStation System (Bochner, 1989). Strain preparation and cultivation were performed according to the supplier's instructions for Gram-positive bacteria, except that the isolates were grown for 3 days to obtain the required inoculum density. Subsequently a GP2 MicroPlate was inoculated with $150 \mu$ l bacterial suspension per well and incubated at $30{ }^{\circ} \mathrm{C}$ for $4-8$ days.

Salt and sucrose tolerance. Salt and sucrose tolerance was first tested in Tryptone Soy Broth (TSB) with added $\mathrm{NaCl}[15,20,25$ and $28.5 \%$ (saturation)] or sucrose [30, 60 and $66 \%$ (saturation)]. Experiments were conducted at $\mathrm{pH} 7.0$, defined as the optimum $\mathrm{pH}$ for growth of T. halophilus by Röling \& van Verseveld (1997), and at $\mathrm{pH}$ 9.0, a typical $\mathrm{pH}$ of non-degraded thick juice. The experiment was performed in closed $50 \mathrm{ml}$ conical tubes with $15 \mathrm{ml}$ of culture under vigorous stirring at $30{ }^{\circ} \mathrm{C}$. Cells were inoculated at a final concentration of $10^{6}$ c.f.u. $\mathrm{ml}^{-1}$ and the ability to grow was judged from visual examination of opacity during 6-18 days incubation. Samples without apparent bacterial growth were plated on TSA for confirmation. To further investigate differences in growth characteristics, all strains were also inoculated in a similar way in standard sterilized thick juice with a Brix index of $69^{\circ} \mathrm{Bx}$ and a pH of 9.3. Plate counts were determined on TSA ( 6 days of incubation at $30{ }^{\circ} \mathrm{C}$ ) after different lengths of incubation. In addition, for two halophilic strains, $\mathrm{T} 11^{\mathrm{T}}$ and T15, growth was monitored during 62 days storage at $30{ }^{\circ} \mathrm{C}$ in thick juice adjusted to a varying Brix index at both $\mathrm{pH} 7.0$ and 9.0. Adjustment of the $\mathrm{pH}$ was done with concentrated $\mathrm{HCl}$.

\section{RESULTS}

\section{RAPD fingerprinting}

In order to make a comprehensive, but well-considered selection of Tetragenococcus strains to study the genetic and physiological differences between different tetragenocci, all strains listed in Table 1 were subjected to a RAPD analysis using the primers RAP1, RAP3 and RAP6. RAPD patterns were obtained with DNA fragment sizes ranging from 100 to $3000 \mathrm{bp}$, and both the presence and the relative intensities of the bands were found to be reproducible for all primers in different runs (data not shown). RAPD analysis of all studied thick juice strains listed in Table 1 with primer RAP3 resulted in 22 distinct fragments (Fig. 1), while RAP1 and RAP6 resulted in 20 and 15 different fragments respectively. All RAPD primers produced seven clearly distinct RAPD profiles as exemplified in Fig. 1 for primer RAP3.

Cluster analysis performed either on the three individual patterns or on the combined dataset resulted in a dendrogram similar to the one shown in Fig. 1. The halophilic Tetragenococcus strains $\mathrm{T} 11^{\mathrm{T}}$, T13, T14, T15 and T19 were grouped into a single cluster (RAPD group V). However, the other halophilic strains, T. muriaticus $\mathrm{T} 12^{\mathrm{T}}$ and T18, landed in a separate group, RAPD group VI and

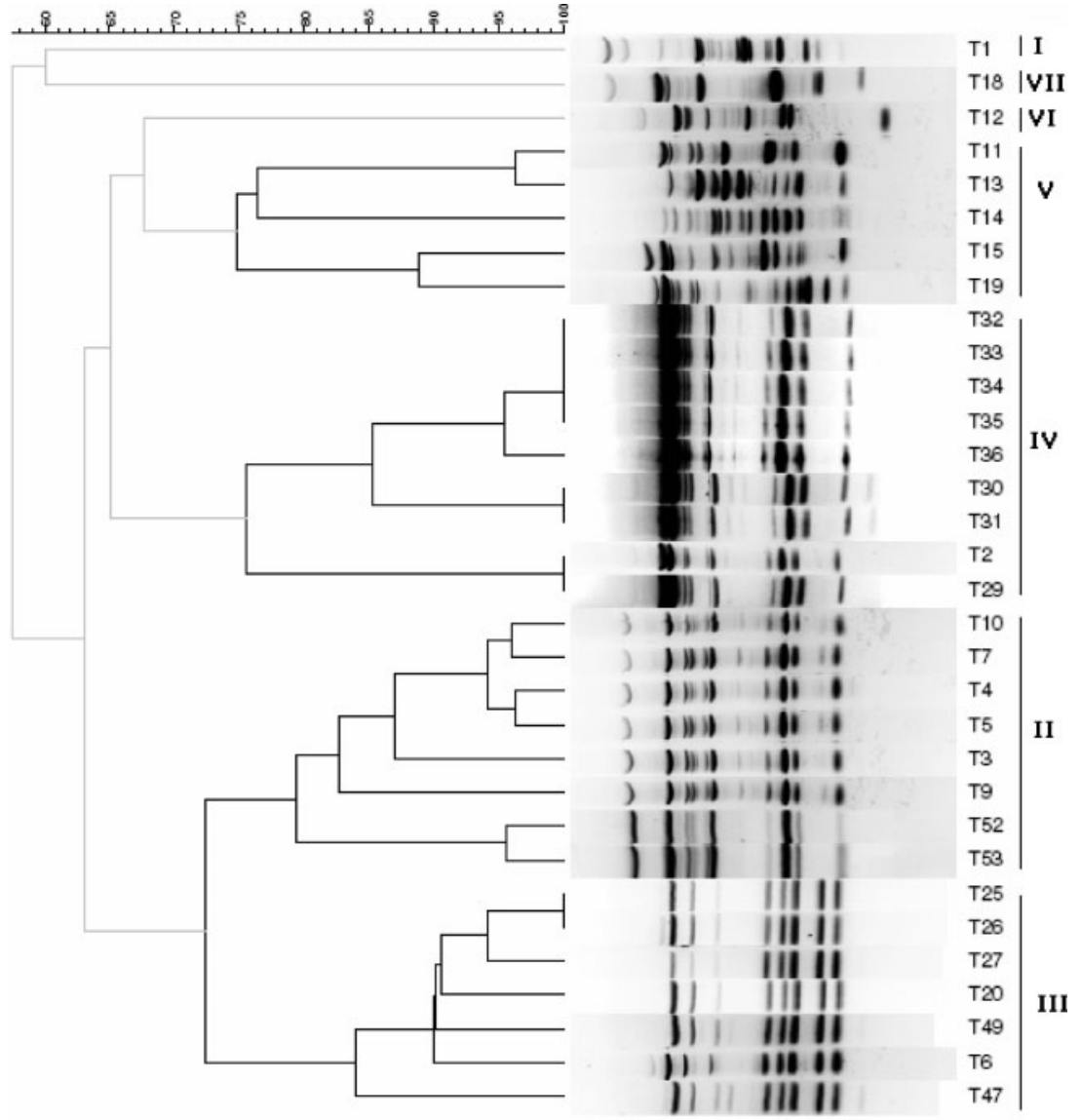

Fig. 1. RAPD fingerprint obtained with primer RAP3 and corresponding dendrogram derived from UPGMA linkage of Pearson correlation coefficients of all Tetragenococcus strains listed in Table 1. 


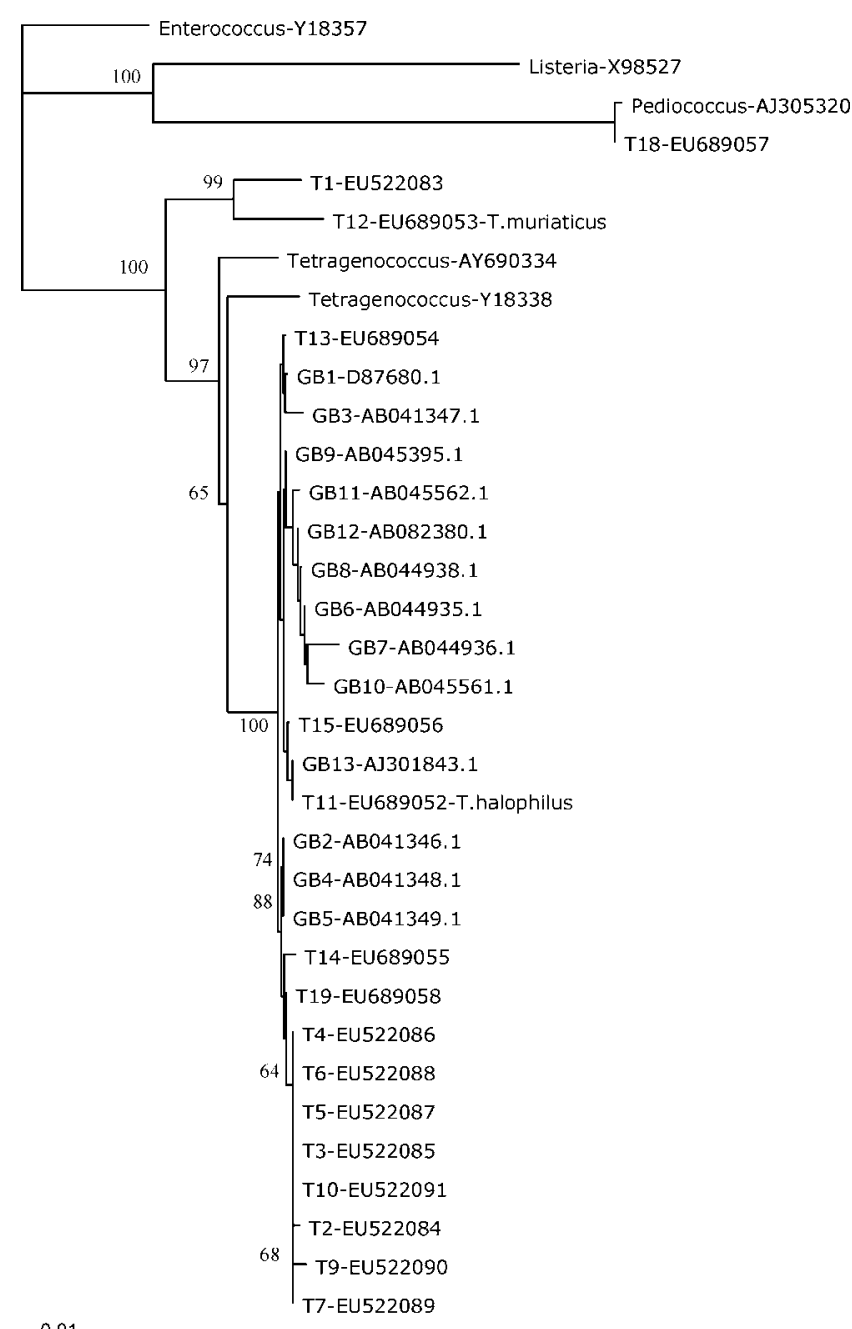

0.01

Fig. 2. Phylogenetic analysis of $16 \mathrm{~S}$ rRNA gene sequences of the selected Tetragenococcus isolates recovered from either sugar thick juice ( $\mathrm{T} 1-\mathrm{T} 7, \mathrm{~T} 9$ and $\mathrm{T} 10)$ or from a salt-rich environment ( $\mathrm{T} 11^{\mathrm{T}}-\mathrm{T} 15$ and $\left.\mathrm{T} 19\right)$, together with all available $T$. halophilus sequences in GenBank (GB1-GB13). Relationships were determined using the neighbour-joining clustering method based on $1077 \mathrm{bp}$. Bootstrap values (based on 100 replications) higher than 60 are shown at the robust nodes of the tree. Strain numbers are accompanied by their respective GenBank accession numbers.

VII, respectively. The osmophilic strains were grouped depending upon the country of origin, with one cluster for almost all Belgian strains (RAPD group II), all French strains (RAPD group IV) and all isolates from Germany (RAPD group III). Only T1 clustered separately from the other tetragenococci (RAPD group I; Fig. 1). Regardless of the refineries of a given country, for each RAPD primer identical patterns were obtained for the different strains (data not shown). No strain pattern could be specifically and systematically associated with degraded or nondegraded thick juice (Fig. 1, Table 1). Based on this extensive RAPD screening, at least one strain per RAPD group was selected for further genetic and physiological characterization. In order to study the association between specific strains from degraded or non-degraded thick juice, five additional $T$. halophilus strains from the Belgian refinery in Tienen, which correspond to previously published work and as a consequence to well-characterized thick juice samples (Justé et al., 2008a, b), were selected in the final set of test strains. Although these strains had an identical RAPD pattern, they were selected because of their different origin: i.e. isolated from degraded or nondegraded thick juice, isolated from thick juice which was or was not treated with hop biocides, and isolated over a period of several years. In total, nine osmophilic (T1-T7, T9 and T10) and seven halophilic strains (T11 ${ }^{\mathrm{T}}-\mathrm{T} 15, \mathrm{~T} 18$ and T19) were retained for further experiments.

\section{5 rRNA gene sequencing and phylogenetic analysis}

To examine the genetic similarity between the selected osmophilic (T1-T7, T9 and T10) and halophilic strains (T11 ${ }^{\mathrm{T}}-\mathrm{T} 15, \mathrm{~T} 18$ and $\left.\mathrm{T} 19\right)$ and to confirm their identity, their 16S rRNA gene sequences were determined and compared with those from GenBank (Table 1). Based on a BLAST analysis, all strains except T18 and T1 were identified as T. halophilus. Isolate T18, which was originally isolated from fermented shrimps, appeared identical with the $16 \mathrm{~S}$ rDNA sequence from a Pediococcus species (GenBank accession no. EU147315.1). T1, which was isolated from degraded sugar thick juice from a Belgian factory, showed most homology to the 16S rDNA of Tetragenococcus muriaticus (GenBank accession no. D88824.1; Table 1).

Furthermore, the sequences of all selected tetragenococci and all available (13) T. halophilus sequences from GenBank (labelled as 'GB') were aligned (1077 bp) and a phylogenetic tree was constructed (Fig. 2). All selected halophilic T. halophilus strains (T11 $\left.{ }^{\mathrm{T}}, \mathrm{T} 13-\mathrm{T} 15, \mathrm{~T} 19\right)$ clustered within the GenBank sequences in a single group (100\% bootstrap support). The osmophilic strains clustered as a subgroup of the T. halophilus cluster (64\% bootstrap support). The $16 \mathrm{~S}$ rDNA sequences from T3, T4, T5, T6, T7 and T10 are identical, while some subtle nucleotide differences were observed with strains $\mathrm{T} 2$ and T9. In addition, $\mathrm{T} 1$ and $\mathrm{T} 12^{\mathrm{T}}$, the type strain of $T$. muriaticus, were clearly separated from the other isolates. Nevertheless, both strains still differed in 25 nucleotides (2\%). All sequences obtained in this study were deposited in GenBank under the accession numbers shown in Fig. 2.

\section{rep-PCR fingerprinting}

rep-PCR fingerprints were generated using the primer set REP1R-I and REP2-I. Cluster analysis clearly separated the osmophilic strains from the halophilic T. halophilus strains (Fig. 3). In contrast to the $16 \mathrm{~S}$ rDNA phylogeny, strain $\mathrm{T} 1$ did not cluster together with the type strain of $T$. 


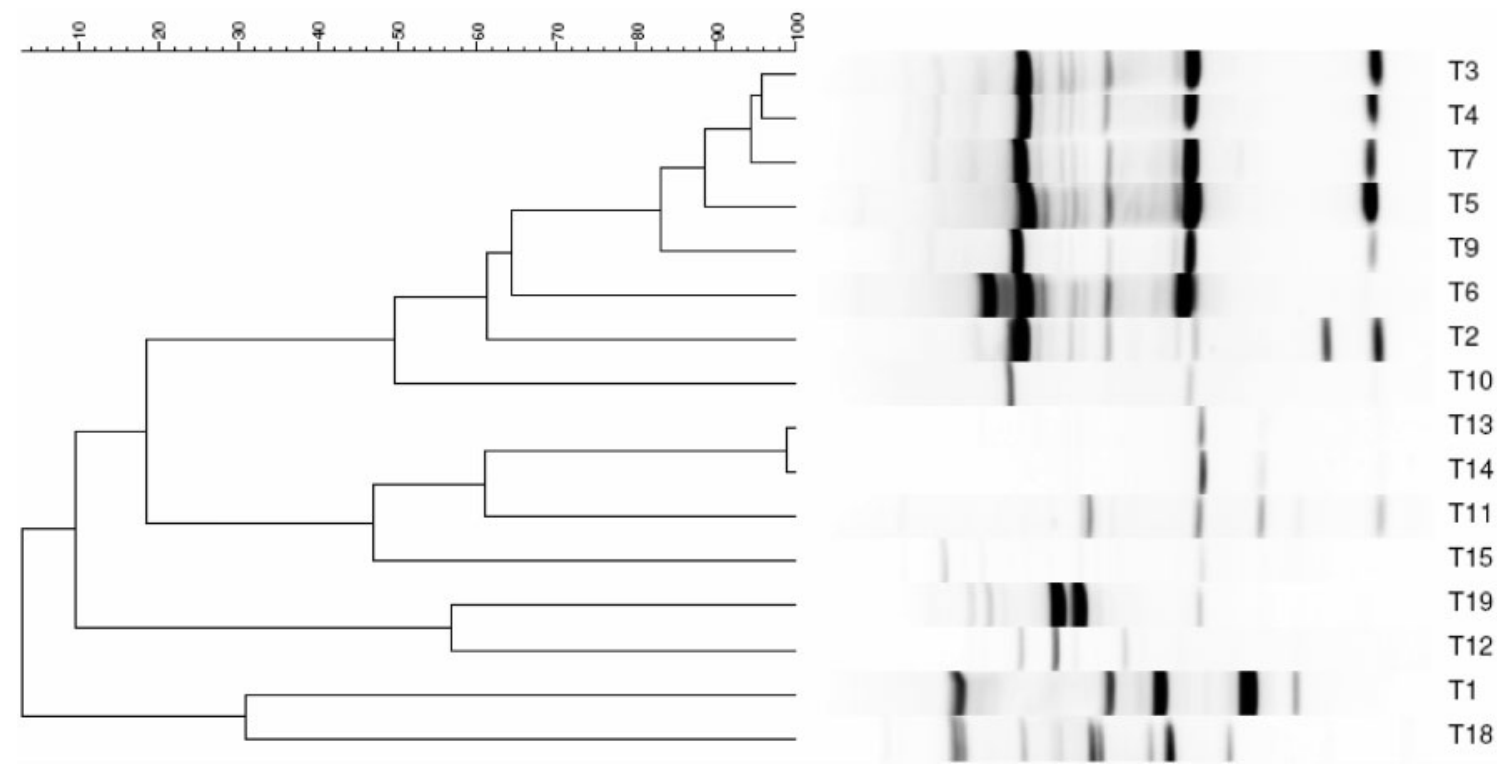

Fig. 3. rep-PCR fingerprint generated using the primer set REP1R-I and REP2-I, and corresponding dendrogram derived from UPGMA linkage of Pearson coefficients of the 16 selected Tetragenococcus strains, isolated either from sugar thick juice (T17, T9 and T10) or from a salt-rich environment (T11 ${ }^{\top}-\mathrm{T} 15, \mathrm{~T} 18$ and $\left.\mathrm{T} 19\right)$.

muriaticus $\mathrm{T} 12^{\mathrm{T}}$, but clustered separately. Similar to the RAPD analyses, no strain pattern could be specifically associated with degraded or non-degraded thick juice. Remarkably, the REP-PCR fingerprint generally produced weaker signals for the halophilic strains than for the osmophilic strains (Fig. 3). Nevertheless, since for all DNA samples (except T10) similar amounts of PCR products were generated using the $16 \mathrm{~S}$ rDNA universal primers $27 \mathrm{~F}$ and 1492R (data not shown), differences in DNA quality may be excluded. Nevertheless, the separate clustering of T10 might be due to the relatively low intensity of the bands obtained (e.g. by a less efficient PCR). Indeed, since clustering was done with the Pearson coefficient, importance is given to the relative intensity of the densitometric curves and not only to presence and/or absence as for Dice correlation coefficients. Clustering with the Dice coefficient showed a similar cluster pattern except that T10 clustered together with T3, T4, T5, T7 and T9 (data not shown). In both cases, the isolates from the refineries from Germany (T6) and France (T2) clustered separately from the isolates obtained from the Belgian refinery [T3, T4, T5, T7, T9 (and T10)] (Fig. 3), in accordance with the RAPD results (Fig. 1).

\section{DNA-DNA hybridization}

Apart from the above-mentioned fingerprinting techniques targeting random or specific DNA sequences in the genome, genetic similarity between the different strains was also measured by DNA-DNA hybridization. Only strains with a different RAPD pattern were selected for this analysis, including the osmophilic strains T1 (RAPD group
I), T2 (RAPD group IV), T5 and T52 (RAPD group II), and T6 (RAPD group III), and the halophilic strains T11 ${ }^{\mathrm{T}}$ (RAPD group V) and T12 ${ }^{\mathrm{T}}$ (RAPD group VI). All strains that were hybridized with the T. halophilus type strain $\mathrm{T} 11^{\mathrm{T}}$ (strains T2, T5, T6 and T52) showed more than $70 \%$ DNA homology with each other (Table 2). As a DNA homology of $70 \%$ is generally accepted as a limit for species delineation (Wayne et al., 1987), it can be concluded that T2, T5, T6 and T52 all belong to the species T. halophilus. Although some of the hybridization results showed variations outside the limits of this method (20-25 units, Goris et al., 1998), these values do not influence the conclusion as presented by the good hybridization values. T1, which shared a similar 16S rDNA sequence with $T$. muriaticus (Table 1, 98\%) but revealed a clearly different RAPD and REP-PCR pattern, showed less than $70 \%$ DNA homology with the T. muriaticus type strain $\mathrm{T} 12^{\mathrm{T}}$ (Table 2 ). Consequently, T1 may represent a novel species of the genus Tetragenococcus.

\section{Biochemical characterization}

Using the Biolog system, the carbon source utilization (SU) pattern of the 15 selected tetragenococci, including nine osmophilic (T1-T7, T9, T10) and six halophilic strains (T11-T15, T19), was analysed. Following the standard protocol for Gram-positive cocci, the five halophilic $T$. halophilus strains $\left(\mathrm{T} 11^{\mathrm{T}}, \mathrm{T} 13-\mathrm{T} 15, \mathrm{~T} 19\right)$ were found to metabolize several substrates, generally corresponding to the findings of Röling \& van Verseveld (1996). In particular, all halophilic isolates were able to utilize 
Table 2. Levels of DNA-DNA reassociation between several Tetragenococcus strains

The type strains T. halophilus LMG $11490^{\mathrm{T}}$ and T. muriaticus LMG $18498^{\mathrm{T}}$ represent the strains $\mathrm{T} 11^{\mathrm{T}}$ and $\mathrm{T} 12^{\mathrm{T}}$, respectively. The numbers in parentheses are the variation between two hybridizations. Technical data with high variations are presented in italics.

\begin{tabular}{|c|c|c|c|c|c|c|c|}
\hline \multirow[t]{2}{*}{ Strain } & \multicolumn{7}{|c|}{ Percentage relatedness to labelled DNA from } \\
\hline & T1 & LMG $18498^{\mathrm{T}}$ & T2 & T5 & T6 & T52 & LMG $11490^{\mathrm{T}}$ \\
\hline $\mathrm{T} 1$ & 100 & & & & & & \\
\hline T. muriaticus $\mathrm{LMG} 18498^{\mathrm{T}}$ & $57(13)$ & 100 & & & & & \\
\hline $\mathrm{T} 2$ & & & 100 & & & & \\
\hline T5 & & & $77(11)$ & 100 & & & \\
\hline T6 & & & $88(14)$ & $85(24)$ & 100 & & \\
\hline T52 & & & $79(23)$ & $97(49)$ & $84(15)$ & 100 & \\
\hline T. halophilus LMG $11490^{\mathrm{T}}$ & & & $80(28)$ & $79(41)$ & $80(66)$ & $79(5)$ & 100 \\
\hline
\end{tabular}

$\alpha$-D-glucose, D-fructose, sucrose, D-mannose, $N$-acetylglucosamine, maltose, methyl $\alpha$-D-glucoside, D-ribose, salicin, methyl pyruvate, pyruvic acid and glycerol. Utilization of $\mathrm{D}$-piscose showed day-to-day variation for isolate $\mathrm{T} 11^{\mathrm{T}}$ and T14. The isolates were unable to utilize $\alpha$-cyclodextrin, $\beta$ cyclodextrin, glycogen, inulin, mannan, L-fucose, D-galacturonic acid, D-gluconic acid, myo-inositol, melezitose, methyl $\beta$-D-galactoside, 3-methylglucose, L-rhamnose, sedoheptulosan, xylitol, D-xylose and L-malic acid, as well as the amino acids and other organic acids in the Biolog plates. Substrates not mentioned were differentially utilized, giving rise to four distinct SU patterns for the five tested isolates (Table 3 ). Strains $\mathrm{T}_{11}^{\mathrm{T}}$ and $\mathrm{T} 14$ gave identical SU patterns. Although these results generally correspond well with the findings of Röling \& van Verseveld (1996), a few differences were observed between the two studies. One example is the positive reaction for all our strains for D-glucose, D-fructose and D-mannose while Röling \& van Verseveld (1996) obtained sometimes surprisingly negative results for these carbon sources. In addition, D-piscose was used by $\mathrm{T} 11^{\mathrm{T}}$ and $\mathrm{T} 14$, while

Table 3. Differential substrate utilization patterns by $T$. halophilus isolates

+ , Positive reaction; -, negative reaction; w, weak or variable reaction.

\begin{tabular}{|lcccc|}
\hline Substrate & $\begin{array}{c}\text { T11 and } \\
\text { T14 }\end{array}$ & T13 & T15 & T19 \\
\hline Arbutin & + & + & - & - \\
Cellobiose & + & + & - & - \\
D-Galactose & + & + & - & - \\
D-Mannitol & - & + & + & - \\
D-Piscose & w & - & - & - \\
Trehalose & + & + & - & - \\
Gentobiose & + & + & - & - \\
Maltotriose & + & - & - & - \\
N-Acetyl-D-mannosamine & + & + & - & w \\
\hline
\end{tabular}

previously all T. halophilus strains were reported not to use this carbon source. On the other hand, the carbon sources arbutin, cellobiose, D-galactose, gentobiose and D-mannitol were not metabolized by any of our strains, in contrast to the observations of Röling \& van Verseveld (1996). The different composition of the plates which were used at that time (B. Bochner personal communication) might explain this discrepancy. In addition, both the growth medium and the incubation conditions used by Röling \& van Verseveld (1996) differed from the protocol we used, and this could also explain the differences. Nevertheless, when we used the protocol of these authors, using TSB $+5 \% \mathrm{NaCl}$ instead of the advised Biolog Universal Growth (BUG) plates with blood, far fewer positive reactions were obtained. In particular, all weak reactions obtained with our protocol were negative when $\mathrm{TSB}+5 \% \mathrm{NaCl}$ was used as growth medium.

In contrast to the halophilic T. halophilus strains, $\mathrm{T} 12^{\mathrm{T}}$, the type strain of $T$. muriaticus, was only able to use a single carbon source, namely glycogen. The osmophilic isolate T1 metabolized a limited number of carbon sources: sucrose, Dfructose, $\alpha$-D-glucose, $N$-acetyl-D-glucosamine, D-mannose and trehalose. The other eight osmophilic isolates produced a negative test result for all carbon sources. Furthermore, an additional French isolate, T30, and German isolate, T20, were analysed and gave identical results. Generally, the use of a carbon source in the Biolog system is indicated by reduction of the colourless tetrazolium violet (TV) to the purple formazan (Bochner, 1989). However, since TV can be toxic to slowly growing bacteria, and in particular to Grampositives, we tested the sensitivity of the tetragenococci for TV by streaking them on TSA plates containing $0.01 \%$ TV and incubating for 8 days at $30{ }^{\circ} \mathrm{C}$. All halophilic strains showed inhibited growth (growth only in densely inoculated zones; no single colonies), but still reduced TV. Most osmophilic strains, however, showed an even more severe inhibition of their growth, and stayed nearly white, illustrating a high sensitivity of these bacteria to TV. Remarkably, osmophilic strains T2 and T6 were not inhibited, but did not reduce TV either. 


\section{Physiological characterization: salt and sucrose tolerance}

To examine physiological differences between the different Tetragenococcus strains isolated from both salt- and sucrose-rich environments, tolerance to these specific osmolytes at different $\mathrm{pH}$ values was tested for a subset of both halophilic (T11 ${ }^{\mathrm{T}}, \mathrm{T} 15$ and $\left.\mathrm{T} 18\right)$ and osmophilic strains (T1, T5 and T9) (data not shown). All strains were able to grow in TSB containing up to $66 \%$ sucrose, at both $\mathrm{pH} 7.0$ and $\mathrm{pH} 9.0$, except T18, which was already inhibited at $25 \%$ sucrose. In addition, all strains could grow in TSB with up to $25 \% \mathrm{NaCl}$ at $\mathrm{pH} 7.0$ and 9.0, although growth was delayed by $\mathrm{NaCl}$ in a concentrationdependent manner (data not shown). The sensitivity to increasing concentrations of $\mathrm{NaCl}$ was greater at $\mathrm{pH} 7.0$ than at $\mathrm{pH} 9.0$, and this led to a remarkable shift in the optimum $\mathrm{pH}$ for growth at the highest $\mathrm{NaCl}$ concentrations $(25 \%$ and $28.5 \%)$. At $25 \% \mathrm{NaCl}$, growth was observed at $\mathrm{pH} 7.0$ and 9.0 after respectively 12 and 8 days. At the saturation level $(28.5 \% \mathrm{NaCl})$, growth only occurred at $\mathrm{pH}$ 9.0. In TSB without extra $\mathrm{NaCl}$ or with $\mathrm{NaCl}$ concentration up to $19 \%$, the Tetragenococcus strains grew faster at $\mathrm{pH} 7.0$, in agreement with the reported optimum $\mathrm{pH}$ for growth of these bacteria (Röling \& van Verseveld, 1997).

To further investigate the physiological differences between all studied strains, the osmophilic and halophilic strains were grown to saturation in TSB and inoculated in sterilized thick juice of $\mathrm{pH} 9.3$ and $69{ }^{\circ} \mathrm{Bx}$ (Table 4). After 7 days, all strains showed a marked reduction in plate

Table 4. Growth and survival of halophilic and osmophilic $T$. halophilus strains after inoculation at $10^{6}$ c.f.u. $\mathrm{ml}^{-1}$ in thick juice of $69^{\circ} \mathrm{Bx}$ and $\mathrm{pH} 9.3$

\begin{tabular}{|lccc|}
\hline \multirow{4}{*}{ Strain } & \multicolumn{3}{c|}{ Counts for T. halophilus $\left(\mathbf{c . f . u .} \mathbf{~ m l}^{-1}\right)^{\star}$ after } \\
storage at $\mathbf{3 0}{ }^{\circ} \mathbf{C}$ for \\
\cline { 2 - 4 } & $\mathbf{7}$ days & $\mathbf{2 1}$ days & $\mathbf{4 7}$ days \\
\hline T1 & $2.6 \times 10^{3}$ & $1.4 \times 10^{4}$ & $>10^{5}$ \\
T2 & $2.0 \times 10^{3}$ & $3.3 \times 10^{2}$ & $>10^{5}$ \\
T3 & $4.3 \times 10^{3}$ & $7.8 \times 10^{3}$ & $>10^{5}$ \\
T4 & $3.0 \times 10^{3}$ & $1.2 \times 10^{4}$ & $>10^{5}$ \\
T5 & $5.6 \times 10^{3}$ & $1.1 \times 10^{3}$ & $>10^{5}$ \\
T6 & $2.0 \times 10^{3}$ & $8.0 \times 10^{3}$ & $>10^{5}$ \\
T7 & $1.3 \times 10^{3}$ & $9.0 \times 10^{3}$ & $>10^{5}$ \\
T9 & $1.7 \times 10^{3}$ & $1.2 \times 10^{3}$ & $>10^{5}$ \\
T10 & $2.0 \times 10^{3}$ & $1.0 \times 10$ & $1.2 \times 10^{4}$ \\
T11 & $1.0 \times 10^{3}$ & $<10$ & $<10$ \\
T13 & $3.0 \times 10^{3}$ & $<10$ & $1.0 \times 10$ \\
T14 & $3.9 \times 10^{3}$ & $2.5 \times 10^{3}$ & $1.0 \times 10^{3}$ \\
T15 & $2.2 \times 10^{3}$ & $5.8 \times 10^{3}$ & $1.8 \times 10^{2}$ \\
T18 & $<10$ & $<10$ & $<10$ \\
T19 & $7.7 \times 10^{2}$ & $2.4 \times 10^{2}$ & $<10$ \\
\hline
\end{tabular}

${ }^{\star}$ On TSA. count from the initial inoculum of $10^{6}$ c.f.u. $\mathrm{ml}^{-1}$ to less than $6 \times 10^{3}$ c.f.u. $\mathrm{ml}^{-1}$. Apparently, an adaptation period was necessary for the cells before they started growing in the thick juice. For strain T18, the count even dropped below the detection limit of 10 c.f.u. $\mathrm{ml}^{-1}$. After 21 days, the counts of all the osmophilic strains, except T2 and T10, had slightly increased. After 47 days, concentrations of higher than $10^{5}$ c.f.u. $\mathrm{ml}^{-1}$ were reached, except for strain T10, which reached $1.2 \times 10^{4}$. In contrast, the counts of all the halophilic isolates continued to decline over the entire duration of the experiment, although this did not occur at the same rate for all strains. The counts after 47 days had dropped below the detection threshold for type strain $\mathrm{T} 11^{\mathrm{T}}$ and strains T18 and T19, and did not exceed $10^{3}$ c.f.u. $\mathrm{ml}^{-1}$ for all the other halophilic strains (Table 4).

Strains $\mathrm{T} 11^{\mathrm{T}}$ and $\mathrm{T} 15$ were chosen to further characterize the growth of the halophiles in thick juice with different solids contents and $\mathrm{pH}$ values. As shown in Table 5, the counts of both strains declined over the entire period of 62 days when the thick juice had a solids content of $65^{\circ} \mathrm{Bx}$ or above. The decline was stronger at $\mathrm{pH} 7.0$ than at $\mathrm{pH} 9.0$, but did generally not significantly differ between the strains or between thick juice of $65^{\circ} \mathrm{Bx}, 67^{\circ} \mathrm{Bx}$ or $69{ }^{\circ} \mathrm{Bx}$, except at $69{ }^{\circ} \mathrm{Bx}$ with $\mathrm{pH} 9$. At $60{ }^{\circ} \mathrm{Bx}$, in contrast, both strains were able to grow, reaching a count of $>10^{5}$ c.f.u. $\mathrm{ml}^{-1}$ at the end of the experiment. However, at $\mathrm{pH} 7.0$, this growth phase was preceded by an initial decline at day 7 , after which growth resumed, whereas at $\mathrm{pH} 9.0$, both strains reached $>10^{5}$ c.f.u. $\mathrm{ml}^{-1}$ already at day 7 .

\section{DISCUSSION}

In this study T. halophilus strains from high-salt and highsugar environments, and in particular from degraded and non-degraded thick juice, were compared in detail. Both physiological and genetic characterization using RAPD technology, REP-PCR, Biolog and growth tolerance revealed clear differences between $T$. halophilus strains isolated from salt- and sugar-rich environments. However, no strain pattern could be specifically and systematically associated with degraded or non-degraded thick juice.

RAPD fingerprinting of 25 thick juice isolates revealed similar patterns for all isolates from the same refinery, regardless of the year of isolation, the condition of the thick juice (degraded or not and hop-treated or not), indicating the existence of a stable in-house flora in each location. This in-house flora was not always producer-specific. All three refineries from France, for example, contained isolates with identical RAPD patterns for 2 years in a row. Röling \& van Verseveld (1996), however, observed very different RAPD patterns for $T$. halophilus strains isolated from different soy sauce manufacturers. As for our results, these patterns were consistent over different years. Also for other microflora, clustering of isolates according to their geographical origin, indicating independent 
Table 5. Growth and survival of the halophilic strains $\mathrm{T} 11^{\top}$ and $\mathrm{T} 15$ after inoculation at $10^{6}$ c.f.u. $\mathrm{ml}^{-1}$ in standard thick juice of varying Brix index and $\mathrm{pH}$

\begin{tabular}{|c|c|c|c|c|c|c|}
\hline \multirow[t]{2}{*}{$\mathrm{pH}$} & \multirow[t]{2}{*}{ Strain } & \multirow[t]{2}{*}{ Brix $\left({ }^{\circ} \mathbf{B x}\right)$} & \multicolumn{4}{|c|}{ Counts for T. halophilus (c.f.u. $\mathrm{ml}^{-1}$ ) ${ }^{\star}$ after storage at $30{ }^{\circ} \mathrm{C}$ for } \\
\hline & & & 7 days & 13 days & 24 days & 62 days \\
\hline \multirow[t]{2}{*}{7} & $\mathrm{~T} 11$ & 60 & $<10$ & $7.0 \times 10$ & $2.0 \times 10$ & $>10^{5}$ \\
\hline & $\mathrm{T} 15$ & & $2.0 \times 10^{3}$ & $4.0 \times 10^{3}$ & $>10^{5}$ & $>10^{5}$ \\
\hline \multirow[t]{2}{*}{7} & $\mathrm{~T} 11$ & 65 & $<10$ & $1.0 \times 10$ & $<10$ & $<10$ \\
\hline & $\mathrm{T} 15$ & & $<10$ & $8.0 \times 10$ & $<10$ & $<10$ \\
\hline \multirow[t]{2}{*}{7} & $\mathrm{~T} 11$ & 67 & $<10$ & $<10$ & $<10$ & $<10$ \\
\hline & $\mathrm{T} 15$ & & $<10$ & $5.0 \times 10$ & $3.0 \times 10$ & $<10$ \\
\hline \multirow[t]{2}{*}{7} & $\mathrm{~T} 11$ & 69 & $<10$ & $<10$ & $<10$ & $<10$ \\
\hline & $\mathrm{T} 15$ & & $<10$ & $1.0 \times 10$ & $<10$ & $<10$ \\
\hline \multirow[t]{2}{*}{9} & $\mathrm{~T} 11$ & 60 & $>10^{5}$ & $>10^{5}$ & $>10^{5}$ & $>10^{5}$ \\
\hline & $\mathrm{T} 15$ & & $>10^{5}$ & $>10^{5}$ & $>10^{5}$ & $>10^{5}$ \\
\hline \multirow[t]{2}{*}{9} & $\mathrm{~T} 11$ & 65 & $2.0 \times 10^{3}$ & $2.0 \times 10^{3}$ & $1.0 \times 10^{3}$ & $2.0 \times 10$ \\
\hline & $\mathrm{T} 15$ & & $2.0 \times 10^{3}$ & $2.0 \times 10^{3}$ & $2.0 \times 10^{3}$ & $1.0 \times 10^{2}$ \\
\hline \multirow[t]{2}{*}{9} & $\mathrm{~T} 11$ & 67 & $2.0 \times 10^{3}$ & $1.5 \times 10^{3}$ & $7.0 \times 10^{2}$ & $7.0 \times 10^{2}$ \\
\hline & $\mathrm{T} 15$ & & $2.0 \times 10^{3}$ & $2.0 \times 10^{3}$ & $2.0 \times 10^{3}$ & $5.0 \times 10^{3}$ \\
\hline \multirow[t]{2}{*}{9} & $\mathrm{~T} 11$ & 69 & $<10$ & $<10$ & $<10$ & $<10$ \\
\hline & $\mathrm{T} 15$ & & $2.0 \times 10^{3}$ & $4.0 \times 10^{3}$ & $3.0 \times 10^{3}$ & $1.0 \times 10^{2}$ \\
\hline
\end{tabular}

${ }^{*}$ On TSA.

evolutionary origins for the different clusters, has been frequently reported (Dyble et al., 2002; Wong et al., 2004).

Based on the RAPD results obtained, nine osmophilic strains were selected for further characterization. All genetic analyses, including RAPD fingerprinting, 16S rDNA phylogenetic analysis and REP-PCR, showed a different clustering for the halophilic and osmophilic $T$. halophilus strains. DNA-DNA hybridization, however, revealed more than $70 \%$ similarity between the two groups of strains, indicating that all strains examined should be considered as members of the same species (Wayne et al., 1987). However, the observation of clear biochemical, physiological and genetic differences between strains from a salt- and sucrose-rich environment might defend the proposal of creating two subspecies of T. halophilus.

In an attempt to characterize the selected strains biochemically using the Biolog carbon source profiling plates, we found that most osmophilic strains were severely inhibited by tetrazolium violet (TV) in the plates. However, two strains, including T2 and T6, were able to tolerate colourless TV, but did not reduce it to the purple formazan, explaining why no fingerprint was generated. Nevertheless, the clear difference in behaviour of the osmophilic versus the halophilic strains indicated a consistent physiological difference between the two groups.

In addition, the observation that the halophilic strains were not able to grow in sugar thick juice with $\geqslant 65^{\circ} \mathrm{Bx}$ confirmed some subtle physiological differences between the osmophilic and halophilic T. halophilus strains (Tables 4 and 5). It has not been examined whether the originally inoculated bacteria had died or were in a viable, but non- culturable state. The differences between these strain groups could in theory be explained by the fact that stress imposed by ions (e.g. salt-rich conditions) and organic solutes (e.g. sucrose-rich conditions) is not necessarily the same (Grant, 2004; Kushner, 1978). However, tolerance to high concentrations of sucrose and $\mathrm{NaCl}$ in TSB was similar for all osmophilic and halophilic strains tested (data not shown). Another hypothesis is that osmophilic and halophilic strains require different nutritional compounds. It is possible that a growth factor crucial for halophiles is not present in thick juice, while TSB contains a broad range of growth factors enabling all T. halophilus strains to grow. An example of such a growth factor in the extreme environment of thick juice could be an osmolyte, and more in particular glycine betaine, since this osmolyte is accumulated in sugar beets under osmotic stress (McCue \& Hanson, 1992). On the other hand, Robert et al. (2000) demonstrated that osmotic tolerance of halophilic $T$. halophilus strains was enhanced by the uptake of glycine betaine, making this hypothesis implausible. In addition, bacterial adaptation to environmental conditions has the potential to alter the genome in such a way that the organism becomes more resistant to further stress (Johnson \& Ogrydziak, 1984; Pérez et al., 2006), which may explain the different behaviour between osmophilic and halophilic strains.

Remarkably, while the optimum $\mathrm{pH}$ for $T$. halophilus growth was 7.0, as determined on GYP agar with $10 \%$ $\mathrm{NaCl}$ and incubation at $30{ }^{\circ} \mathrm{C}$ (Röling \& van Verseveld, 1997), at extremely low $a_{\mathrm{w}}$ values $\mathrm{pH} 9.0$ was preferred, regardless of whether osmotic stress was created by sucrose or $\mathrm{NaCl}$ (data not shown). A similar observation was made 
for the cyanobacterium Aphanothece halophytica (Laloknam et al., 2006), for which it was found that a betaine transporter specifically catalyses the uptake of the osmoregulator betaine and that uptake activities are high at alkaline $\mathrm{pH}$. In general, $\mathrm{H}^{+}$uptake by the $\mathrm{Na}^{+} / \mathrm{H}^{+}$ antiporter is important to keep the cytoplasmic $\mathrm{pH}$ neutral, and the $\mathrm{Na}^{+} / \mathrm{H}^{+}$antiporter could extrude $\mathrm{Na}^{+}$from the cell. To maintain homeostasis at alkaline $\mathrm{pH}$, a re-entry route for $\mathrm{Na}^{+}$is required (Padan et al., 2005). The $\mathrm{Na}^{+}$/ betaine symporter was suggested to be a re-entry route (Laloknam et al., 2006), explaining the unusual enhanced growth at pH 9.0 at high salinity (Padan et al., 2005). Diluting thick juice with sterilized water enables the halophilic strains to grow (better) in thick juice, supporting the hypothesis that an osmolyte enabling the halophilic strains to grow in thick juice is missing. A Brix index of $60{ }^{\circ} \mathrm{Bx}$ (or $a_{\mathrm{w}} 0.89$ ) enabled halophilic T. halophilus strains to grow (Table 5).

In all analyses performed, $\mathrm{T} 1$, which was originally isolated from degraded thick juice from a Belgian factory, showed a different behaviour compared to the other Tetragenococcus strains. Based on $16 \mathrm{~S}$ rDNA sequence analysis this strain was closely related $(98 \%)$ to the T. muriaticus type strain $\left(\mathrm{T} 12^{\mathrm{T}}\right)$. However, since the DNA-DNA hybridization level between the two strains was rather low (Table 2), strain T1 is likely to represent a new Tetragenococcus species. Description and designation of a species name will be presented elsewhere.

Despite the diversity found among T. halophilus strains in this study, no strain could be associated with degraded or non-degraded thick juice. As a consequence, different physiological parameters of the thick juice itself might be responsible for the variable behaviour of $T$. halophilus (Justé et al., 2008b), creating more favourable or unfavourable conditions for thick juice degradation. Moreover, poor storage conditions can occur locally in a storage tank, including a low Brix index or a high temperature (Justé et al., 2008a), or perhaps a critical oxygen concentration (Kanbe \& Uchida, 1982) enabling exponential growth of $T$. halophilus and thick juice degradation. Further research on storage of differently conditioned thick juice inoculated with the same strain of $T$. halophilus is necessary to elucidate the different behaviour of dominant populations of $T$. halophilus in sugar thick juice. A fuller characterization of the conditions with and without degradation might facilitate more efficient process control and possibly prevention of thick juice degradation.

\section{ACKNOWLEDGEMENTS}

The authors thank the Südzucker company and the De Nayer Institute for financing the $\mathrm{PhD}$ of A. Justé. I. Frans is financially supported by the 'Vlaams Instituut voor de bevordering van het Wetenschappelijk-Technologisch Onderzoek Vlaanderen' (IWT 70113) B. L. is supported by De Ceuster Corp. (Sint-KatelijneWaver, Belgium) and the 'Vlaams Instituut voor de bevordering van het Wetenschappelijk-Technologisch Onderzoek Vlaanderen' (IWT 70113). We are truly grateful to Dr P. van Baarlen for help with the phylogenetic analysis. In addition, we are grateful to the Tiense Suikerraffinaderij (Tienen, Belgium) and Südzucker (Germany) for supplying the thick juice and their committed cooperation. Finally, we acknowledge Christel Verreth for technical assistance and in particular Barry Bochner for his helpful advice.

\section{REFERENCES}

Altschul, S. F., Madden, T. L., Schaffer, A. A., Zhang, J., Zhang, Z., Miller, W. \& Lipman, D. J. (1997). Gapped BLAST and PSI-BLAST: a new generation of protein database search programs. Nucleic Acids Res 25, 3389-3402.

Benson, D. A., Karsch-Mizrachi, I., Lipman, D. J., Ostell, J. \& Wheeler, D. L. (2004). Genbank: update. Nucleic Acids Res 32, D23-D26.

Bochner, B. (1989). Breathprints at the microbial level. An automated redox-based technology quickly identifies bacteria according to their metabolic capacities. ASM News 55, 536-539.

Chen, Y.-S., Yanagida, F. \& Hsu, J.-S. (2006). Isolation and characterization of lactic acid bacteria from suan-tsai (fermented mustard), a traditional fermented food in Taiwan. J Appl Microbiol 101, 125-130.

Cleenwerck, I., Vandemeulebroecke, K., Janssens, D. \& Swings, J. (2002). Re-examination of the genus Acetobacter, with descriptions of Acetobacter cerevisiae sp. nov. and Acetobacter malorum sp. nov. Int J Syst Evol Microbiol 52, 1551-1558.

Collins, M. D., Williams, A. M. \& Wallbanks, S. (1990). The phylogeny of Aerococcus and Pediococcus as determined by $16 \mathrm{~S}$ rRNA sequence analysis: description of Tetragenococcus gen. nov. FEMS Microbiol Lett 58, 255-262.

Dyble, J., Paerl, H. W. \& Neilan, B. A. (2002). Genetic characterization of Cylindrospermopsis raciborskii (Cyanobacteria) isolates from diverse geographic origins based on nifH and $c p c B A$-IGS nucleotide sequence analysis. Appl Environ Microbiol 68, 2567-2571.

Ennahar, S. \& Cai, Y. (2005). Biochemical and genetic evidence for the transfer of Enterococcus solitarius Collins et al. 1989 to the genus Tetragenococcus as Tetragenococcus solitarius comb. nov. Int J Syst Evol Microbiol 55, 589-592.

Ezaki, T., Hashimoto, T. \& Yabuuchi, E. (1989). Fluorometric deoxyribonucleic acid-deoxyribonucleic acid hybridization in microdilution wells as an alternative to membrane filter hybridization in which radioisotopes are used to determine genetic relatedness among bacterial strains. Int J Syst Bacteriol 39, 224-229.

Goris, J., Suzuki, K., De Vos, P., Nakase, T. \& Kersters, K. (1998). Evaluation of a microplate DNA-DNA hybridization method compared with the initial renaturation method. Can J Microbiol 44, 1148-1153.

Grant, W. D. (2004). Life at low water activity. Philos Trans $R$ Soc Lond B Biol Sci 359, 1249-1267.

Ito, H., Hadioetomo, R. S., Nikkuni, S. \& Okada, N. (1985). Studies on lactic acid bacteria in fish sauces (part 2). Identification of salttolerance and acid-producing bacteria from fish sauces. Rep Natl Food Res Inst 47, 31-40.

Johnson, A. R. \& Ogrydziak, D. M. (1984). Genetic adaptation to elevated carbon dioxide atmospheres by Pseudomonas-like bacteria isolated from rock cod (Sebastes spp.). Appl Environ Microbiol 48, 486-490.

Justé, A., Krause, M. S., Lievens, B., Klingeberg, M., Michiels, C. W. \& Willems, K. A. (2008a). Protective effect of hop $\beta$-acids on microbial degradation of thick juice during storage. J Appl Microbiol 104, 51-59. 
Justé, A., Lievens, B., Klingeberg, M., Michiels, C. W., Marsh, T. L. \& Willems, K. A. (2008b). Predominance of Tetragenococcus halophilus as the cause of sugar thick juice degradation. Food Microbiol 25, 413-421.

Kanbe, C. \& Uchida, K. (1982). Diversity in the metabolism of organic acids by Pediococcus halophilus. Agric Biol Chem 46, 2357-2359.

Kobayashi, T., Kimura, B. \& Fuji, T. (2000). Differentiation of Tetragenococcus populations occurring in products and manufacturing processes of puff fish ovaries fermented with rice-bran. Int J Food Microbiol 56, 211-218.

Kobayashi, T., Kajiwara, M., Wahyuni, M., Kitakado, T., HamadaSato, N., Imada, C. \& Watanabe, E. (2003). Isolation and characterization of halophilic lactic acid bacteria isolated from "terasi" shrimp paste: a traditional fermented seafood product in Indonesia. J Gen Appl Microbiol 49, 279-286.

Kushner, D. J. (1978). Life in high salt and solute concentrations. In Microbial Life in Extreme Environments, pp. 318-368. Edited by D. J. Kushner. London: Academic Press.

Laloknam, S., Tanaka, K., Buaboocha, T., Waditee, R., Incharoensakdi, A., Takashi Hibino, T., Tanaka, Y. \& Takabe, T. (2006). Halotolerant cyanobacterium Aphanothece halophytica contains a betaine transporter active at alkaline $\mathrm{pH}$ and high salinity. Appl Environ Microbiol 72, 6018-6026.

Lane, D. J. (1991). $16 \mathrm{~S}$ and $23 \mathrm{~S}$ rRNA sequencing. In Nucleic Acids Techniques in Bacterial Systematics, pp. 115-175. Edited by E. Stackebrandt \& M. Goodfellow. Chichester, UK: Wiley.

Lane, S., Evermann, J., Loge, F. \& Call, D. R. (2004). Amplicon secondary structure prevents target hybridisation to oligonucleotide microarrays. Biosens Bioelectron 20, 728-735.

Lee, M., Kim, M. K., Vancanneyt, M., Swings, J., Kim, S. H., Kang M. S. \& Lee, S. T. (2005). Tetragenococcus koreensis sp. nov., a novel rhamnolipid-producing bacterium. Int J Syst Evol Microbiol 55, 1409 1413 .

Lievens, B., Brouwer, M., Vanachter, A. C. R. C., Lévesque, C. A., Cammue, B. P. A. \& Thomma, B. P. H. J. (2003). Design and development of a DNA array for rapid detection and identification of multiple tomato vascular wilt pathogens. FEMS Microbiol Lett 223, $113-122$.

McCue, K. F. \& Hanson, A. D. (1992). Salt-inducible betaine aldehyde dehydrogenase from sugar beet: cDNA cloning and expression. Plant Mol Biol 18, 1-11.

Padan, E., Bibi, E., Ito, M. \& Krulwich, T. A. (2005). Alkaline pH homeostasis in bacteria: new insights. Biochim Biophys Acta 1717, 67-88.

Pérez, J. E., Nirchio, M., Alfonsi, C. \& Muñoz, C. (2006). The biology of invasions: the genetic adaptation paradox. Biol Invasions 8, $1115-1121$.

Robert, H., Le Marrec, C., Blanco, C. \& Jebbar, M. (2000). Glycine betaine, carnitine, and choline enhance salinity tolerance and prevent the accumulation of sodium to a level inhibiting growth of Tetragenococcus halophila. Appl Environ Microbiol 66, 509-517.
Röling, W. F. M. \& van Verseveld, H. W. (1996). Characterization of Tetragenococcus halophila populations in Indonesian soy mash (kecap) fermentation. Appl Environ Microbiol 62, 1203-1207.

Röling, W. F. M. \& van Verseveld, H. W. (1997). Growth, maintenance and fermentation pattern of the salt-tolerant lactic acid bacterium Tetragenococcus halophila in anaerobic glucose limited retention cultures. Antonie Van Leeuwenhoek 72, 239-243.

Röling, W. F. M., Timotius, K. H., Prasetyo, A. B., Stouthamer, A. H. \& van Verseveld, H. W. (1994). Changes in microflora and biochemical composition during the baceman stage of traditional Indonesian kecap (soy sauce) production. J Ferment Bioeng 77, 62-70.

Sargent, D., Briggs, B. \& Spencer, S. (1997). Thick juice degradation during storage. Zuckerindustrie (Germany) 122, 615-621.

Satomi, M., Kimura, B., Mizoi, M., Sato, T. \& Fujii, T. (1997). Tetragenococcus muriaticus sp. nov., a new moderately halophilic lactic acid bacterium isolated from fermented squid liver sauce. Int $J$ Syst Bacteriol 47, 832-836.

Thongsant, J., Tanasupawat, S., Keeratipibul, S. \& Jatikavanich, S. (2002). Characterization and identification of Tetragenococcus halophilus and Tetragenococcus muriaticus strains from fish sauce (Nampla). Jap J Lactic Acid Bacteria 13, 46-52.

Uchida, K. \& Kanbe, C. (1993). Occurrence of bacteriophages lytic for Pediococcus halophilus, a halophilic lactic-acid bacterium, in soy sauce fermentation. J Gen Appl Microbiol 39, 429-437.

Versalovic, J., Schneider, M., De Bruijn, F. J. \& Lupski, J. R. (1994). Genomic fingerprinting of bacteria using repetitive sequence-based polymerase chain reaction. Methods Mol Cell Biol 5, 25-40.

Villar, M., Holgado, A. P., Sanchez, J. J., Trucco, R. E. \& Oliver, G. (1985). Isolation and characterization of Pediococcus halophilus from salted anchovies (Engraulis anchoita). Appl Environ Microbiol 49, 664-666.

Wayne, L. G., Brenner, D. J., Colwell, R. R., Grimont, P. A. D., Kandler, O., Krichevsky, M. I., Moore, L. H., Moore, W. E. C., Murray, R. G. E. \& other authors (1987). International Committee on Systematic Bacteriology. Report of the ad hoc committee on reconciliation of approaches to bacterial systematics. Int J Syst Bacteriol 37, 463-464.

Willems, K. A., Willems, M. L., Dardenne, F., Klingeberg, M., Michelberger, T. \& Witte, G. (2003). Microbiological observations during storage of thick juice on a pilot and industrial scale. In Proceedings of the CITS 2003, 22nd General Assembly Madrid, Spain, 18-21 May 2003.

Wilson, K. (1987). Preparation of genomic DNA from bacteria. In Current Protocols in Molecular Biology, pp. 2.4.1-2.4.5. Edited by F. M. Ausubel, R. Brent, R. E. Kingston, D. D. Moore, J. G. Seidman, J. A. Smith \& K. Struhl. New York: Green Publishing and WileyInterscience.

Wong, H.-C., Chen, S.-Y., Chen, M.-Y., Oliver, J. D., Hor, L.-I. \& Tsai, W.-C. (2004). Pulsed-field gel electrophoresis analysis of Vibrio vulnificus strains isolated from Taiwan and the United States. Appl Environ Microbiol 70, 5153-5158.

Edited by: H.-P. Klenk 